Tezer, M., Gülyaz C. M., \& Illdırımlı, A. (2020). Examination of mathematics study strategies of secondary school students from the perspective of multiple variables, International Journal of Cognitive Research in Science, Engineering and Education (IJCRSEE), 8(3), 83-92.

Original scientific paper

UDK:

Received: September, 10.2020.

Revised: October, 20.2020.

Accepted: October, 29.2020.

\title{
Examination of Mathematics Study Strategies of Secondary School Students From the Perspective of Multiple Variables
}

\author{
Murat Tezer ${ }^{1 *}$, Meryem Gülyaz Cumhur ${ }^{1}$, Aytan IIdırımlı1
}

\author{
${ }^{1}$ Near East University, Arts and Sciences faculty, Primary Mathematics Education Department, Northern Cyprus \\ e-mail: murat.tezer@neu.edu.tr; meryem.cumhur@neu.edu.tr; ayten.at63@gmail.com
}

\begin{abstract}
The academic achievement of students can decrease if they fail to use mathematics study strategies well. This situation may lead to negative opinions and attitudes among students towards mathematics. In this study, it was aimed to examine the mathematics study strategies of students enrolled at secondary schools in terms of academic achievement and multiple variables. Relational survey method, one of the quantitative research methods, was used to obtain the data. The universe of the study consists of a total of 9,072 students in the $6^{\text {th }}, 7^{\text {th }}$ and $8^{\text {th }}$ grades of secondary schools under the Secondary Education Office of the Ministry of National Education and Culture of Northern Cyprus during the 2019-2020 academic year. In the study, the simple random sampling method was used to include 1,012 students. In order to collect the research data, the mathematics study strategies of secondary school students were used; on the other hand, mathematics grades were employed to assess their academic achievement. As a result of the research, when the mathematics study strategies of secondary school students are examined, it is seen that their mathematics study strategies are at the medium level. In this study, a comparison of mathematics study strategies in terms of gender showed that the average score of female students for mathematics study strategies was higher compared to the males. It was also seen that students' mathematics study strategy scores were similar regardless of whether they were attending extra-school study centres or preparatory schools, and students' mathematics study strategies scores were similar regardless of whether they received private tutoring. Regardless of the grade levels of the students, we can also claim that their mathematics study strategies are at the medium level. Generally, it has been observed that secondary school students with high academic achievement use their mathematics study skills better than students with low academic achievement.
\end{abstract}

Keywords: study strategy, mathematics, secondary school, students, achievement.

\section{Introduction}

The evolving world needs people who understand themselves and their environment well, and who know in what way they think. Mathematics is one of the most important instruments that is known to improve thinking. For this reason, mathematics education is one of the most important building blocks of basic education (Umay, 2003). Recently, there have been critical changes in the perspectives of education, mathematics, and mathematics education. Mathematics education aims to raise people who not only know mathematics but also practice what they know, do mathematics, solve problems, communicate, and enjoy doing these things. Such an objective requires change (Yaman, Olkun and Toluk, 2003).

One of the important factors affecting students' level of success at school is their study strategy. The concept of strategy is a word used primarily used by military services. A strategy is a plan prepared to conduct military activities (Whitworth, Herzog and Scott, 2012). Generally speaking, when a strategy is mentioned, it is expressed as the way of obtaining something, or the applications made within the framework of a plan developed to reach a certain goal. People become successful when they follow a certain plan in order to achieve a certain goal. As a result, there are always methods that people can follow in order to ensure their desired learning. All this can be defined under the term learning strategy (Açıkgöz, 2003).

Learning strategies make it easy to possess thoughts, behaviours, beliefs or feelings, to understand, or to transfer old knowledge and behaviour into new ones (Weinstein, Husman and Dierking, 2000). In terms of learning strategy, several different methods and ways have been suggested. One of these is explained as follows (Arries, 1999): The ability to identify strategies step by step, to list teaching approaches and learning materials, to model, implement with guidance, to apply independently, to capture opportunities

${ }^{*}$ Corresponding author: murat.tezer@neu.edu.tr 
Tezer, M., Gülyaz C. M., \& Illdırımlı, A. (2020). Examination of mathematics study strategies of secondary school students from the perspective of multiple variables, International Journal of Cognitive Research in Science, Engineering and Education (IJCRSEE), 8(3), 83-92.

to transfer skills and ideas from one situation to another, to develop the ability to establish meaningful connections between skills and ideas, to find opportunities to show what they know, self-monitoring and self-control, and developing tools to evaluate one's self-learning.

While Hoover and Patton (1995) explained study skills as all of the processes that involve acquiring, organizing, synthesizing, remembering and using information, Kartika (2007) defined them as the reading and thinking required for any task involving work. Crede and Kuncel (2008) defined study skills as the student knowing the study strategies and methods and using the time and resources appropriately to fulfil the desired task. Pohl (2020), on the other hand, explained study skills as techniques and strategies that help the individuals recall what they read and hear for specific purposes.

An appropriate study strategy can have a positive impact on school success. The strategy used is one of the most important aspects of study mathematics. A person who can determine a study strategy achieves the desired result more easily. A person's ability to strategy to solve the problem that they are working on shows that he / she largely has command of the topic. Each person's study strategy is different. A particular study strategy may seem easy to some people and difficult to others. Therefore, it is possible to produce more than one study strategy for a problem (Qu, Wang and Zhong, 2009).

Learning, and using strategies of learning and studying by students is as important as learning other courses. Enabling students to acquire learning and study strategies means helping them learn and succeed by understanding the lessons. When students excessively, this may not always guarantee them success. Students should know what to do and how to do it at all times in addition to studying hard. One of the main factors in achieving this is that students should be proficient in effective study strategies and methods (Willems and Bossche, 2019).

Learning, perceiving and using strategies of learning and studying by students affect their level of success deeply. The success rate of students who learn and use these strategies positively is higher than those who study without using strategies. Today's education model incorporates an examination system in which very slight changes in the grades can impact their future lives. Today's students, who have to leave hundreds of friends behind to pursue higher education, should have very good learning and study strategies. With each passing day, the number of students is increasing and competition is becoming more intense. For this reason, it is important that students have a good learning and study strategy (Rohman, Hobri and Sahnawi, 2019).

It is aimed for students to understand mathematical concepts in the secondary school mathematics curriculum, to establish a relationship between concepts, to reach a new concept with reasoning (judgement) skills, to solve daily life problems, to establish models, and to associate these models with mathematical concepts. It is known that the ability of students to reach the achievements in the curriculum by themselves will enable learning to become permanent in their minds, and the ability to establish relationships and reasoning between the achievements will positively affect the students' mathematics achievement. The Secondary School Mathematics Curriculum consists of five learning areas: Numbers and Operations, Algebra, Geometry and Measurement, Data Processing, and Probability (Ministry of Education and Culture, 2016).

The study strategy is one of the most important factors that affects the academic achievement of students. The correct choice of study strategy has a positive impact on school success. The strategy is one of the most important aspects of studying mathematics. Those students who determine the study strategy correctly can reach the desired results more easily. When a person determines an appropriate strategy to solve the problem that he/she is working on, this shows that he/she largely has command of the topic. Each person's study strategy is different. A particular study strategy may seem easy for one person and difficult for another. Therefore, it is possible to produce more than one study strategy for a problem (Coendars and Verhoef, 2019).

Another variable of study strategies is the positive self-image of the individual and his/her positive image towards the school and the teaching staff. It is believed that students who think that they are more successful will have more positive attitudes towards studying and use more effective study strategies. One of the correct study strategies is the efficient use of time. Time should be used correctly, not only in terms of courses, but also in people's lives in general. All people should use time correctly and effectively. Students must use this strategy appropriately in order to be successful at school and in their educational lives. The scope of knowledge, skills, behaviours and habits that students need to learn as they move to higher grades increases further. The scope and content of lessons, especially those such as mathematics, increase more. In this respect, they must determine correct and easy strategies for studying, one of the most important of which is time management. Therefore, students must manage their time correctly during the course of studying (Lewis, Perry and Hurd, 2009).

Some students frequently mention that although they study hard, this is not reflected in their levels 
of achievement in classes. According to Song et al. (2020), the important factor here is that efficiency obtained from studying is not a function of the time spent studying. What is most important in studying is that time is managed well and high efficiency is obtained.

Students understanding the nature of study strategies and using them is as important as learning a different course. Their knowledge of learning and study strategies means that they can understand classes better and that they can receive help in understanding lessons. When students study when taking courses, they may not always guarantee them success. In addition to studying, students must know what they should do and how they should do it. One of the most important factors in this respect is that students should have the ability to adopt study strategies and methods (Holm, Hausman and Rhodes, 2020). An examination of the literature shows that there is a strong correlation between academic achievement and studying habits (Bergey et al., 2019). For this reason, one of the most important tasks of educationists is to ensure that students make maximum use of education activities and improve their study strategies to a more effective and efficient level.

More importance is being given to education and teaching and the number of students is continuing to increase on global scale. As a result of this increase, an examination of the mathematics study strategies of students, and determination of the factors that positively or negatively affect teaching and education, will result in an improvement in the quality of the education systems around the world. Considering the findings of previous studies, the examination of mathematics study strategies of secondary school students will provide benefits, especially in terms of the success in mathematics for mathematics teachers and students alike. The objective of this paper is to examine the mathematics study strategies of secondary school students from the perspective of academic achievement and multiple variables. In accordance with the objective of this paper, the following sub-objectives have been identified:

- What is the nature of the mathematics study strategies of secondary school students?

- Is there a significant difference between the mathematics study strategies of secondary school students from the perspective of gender, whether they attend an extra-school study centre or school, or are receiving private tutoring for mathematics, grade, and their academic achievement?

\section{Materials and Methods}

\section{Research Method}

The objective of this study is to examine the mathematics study strategies of secondary school students and their relation with academic achievement from the perspective of multiple variables; thus, the relational survey model was used in the research. Karasar (2006) described the relational survey model as a "research model aiming to determine the presence and / or degree of co-variation between two or more variables".

\section{Population and Sample}

The universe of this research comprised a total of 9,702 students enrolled in the $6^{\text {th }}, 7^{\text {th }}$ and $8^{\text {th }}$ grades of secondary schools affiliated with the Ministry of National Education, Directorate of Secondary Education in Northern Cyprus. During the selection of the research sample, 622 students were determined according to $5 \%$ margin of error and $99 \%$ confidence interval. However, in order to increase the generalizability of the research, this number was exceeded and a total of 1,012 students were included in the study by using a simple random sampling method. Variables

Frequency and Percentages of the Students Constituting the Sample According to Demographic

Of the 1,012 secondary school students included in the study, $47.4 \%$ were girls and $52.6 \%$ were boys. $19.5 \%$ of the students were $6^{\text {th }}$ grade students, $55.1 \%$ were $7^{\text {th }}$ grade students and $25.4 \%$ were $8^{\text {th }}$ grade students (Table 1).

Only $24.3 \%$ of the students included in the study stated that they attended extra-school study centres or preparatory schools, and $75.7 \%$ of them did not. It was observed that $17.4 \%$ of the students received private tutoring and $82.6 \%$ did not receive private tutoring. Thus, the majority of the students participating in the research did not receive private tutoring. Additionally, the average mathematics grade of the secondary school students included in the research at the end of the previous semester was 6.60 out of 10 and the standard deviation was 2.377(Table 1). 
Tezer, M., Gülyaz C. M., \& İlırımlı, A. (2020). Examination of mathematics study strategies of secondary school students from the perspective of multiple variables, International Journal of Cognitive Research in Science, Engineering and Education (IJCRSEE), 8(3), 83-92.

Table 1 Variables

Frequency and Percentages of the Students Constituting the Sample According to Demographic

\begin{tabular}{lll}
\hline & $\mathbf{N}$ & $\mathbf{\%}, \overline{\boldsymbol{X}}$ - Sd \\
\hline Gender & & \\
$\quad$ Girl & 480 & 47.4 \\
$\quad$ Boy & 532 & 52.6 \\
Grade & & \\
$6^{\text {th }}$ Grade & 197 & 19.5 \\
$7^{\text {th }}$ Grade & 558 & 55.1 \\
$8^{\text {th }}$ Grade & 257 & 25.4 \\
Extra-school study & & \\
$\quad$ centre/preparatory school & & \\
$\quad$ Yes & 246 & 75.3 \\
$\quad$ No & 766 & 17.4 \\
Receive Private Tutoring & & 82.6 \\
$\quad$ Yes & 176 & $6.60-2.377$ \\
$\quad$ No & 836 & 100,0 \\
Average Math Grade & 1012 & \\
Total & 1012 & \\
\hline
\end{tabular}

\section{Data Collection Tool}

In this research, the mathematics study strategies scale of secondary school students was used to collect data. The participants of the research were also asked about their gender, class, whether they attended any extra-school study centre or preparatory school, received private tutoring for mathematics, and their academic achievements at the end of the semester. The scale was used in the research after obtaining the necessary permissions by contacting the authors of the "Mathematics Study Strategies Scale" developed by Aslan (2008). The scale has four factors and comprises 35 items. These factors are time management strategies, executive cognition strategies, cognitive strategies and test strategies, respectively.

The basis of the time management strategy is to know how time is spent, as well as planning the time spent working within the remaining time after time management for various personal needs. Woolfolk (1993) expresses executive cognition strategies as skills to monitor learning effectively during learning. Cognitive strategies include competencies such as obtaining information, controlling attention, and developing methods of remembering (Schuster et al., 2020). Transfer of metacognitive skills in selfregulated learning: an experimental training study (Schuster et al, 2020). Testing strategies, summaries of topics covered by the test. It includes repeating summaries, answering questions about the same issues that have been solved before, working hard on lesser known issues and having preliminary information that guides test preparation (Murry, 1990).

The 5-point Likert scale is ranked from the highest to the lowest score, "strongly agree (5)", "agree (4)", "indecisive (3)", "disagree (2)" and "disagree totally (1)" and scores were calculated accordingly. It is necessary to test the reliability of each factor that constitutes the scale. The Cronbach's alpha reliability coefficient calculated for the overall scale was 0.90 . In this study, the Cronbach's alpha reliability coefficient calculated for the overall scale is 0.92 . For this reason, it can be stated that the scale is very reliable.

\section{Analysis of Data}

Statistical Package for Social Sciences SPSS 24.0 software was used for statistical analysis of the research data. In statistical analysis, the level of significance was taken as .05. Preliminary analysis was performed with SPSS to test the data for normality. It was understood using the Kolmogorov-Smirnov test that the distribution of dependent variables was not normal in the subgroups $(p<0.05)$. For this reason, non-parametric tests were used in this study. Average and standard deviation values were given for the explanations of the items of the scales.

While the significance of the differences between the mean scores was tested in the study, in cases where the variable has two subgroups, a non-parametric test was used for independent samples, namely the Mann-Whitney $\mathrm{U}$ test. As the Kruskal Wallis $\mathrm{H}$ test did not show a normal distribution, the Kruskal Wallis $\mathrm{H}$ test was applied to determine whether the difference between the mean of more than 
Tezer, M., Gülyaz C. M., \& İlırımlı, A. (2020). Examination of mathematics study strategies of secondary school students from the perspective of multiple variables, International Journal of Cognitive Research in Science, Engineering and Education (IJCRSEE), 8(3), 83-92.

two unrelated samples was significantly different and to identify the level of relationship between two dependent variables (Büyüköztürk, 2019). Cronbach's alpha (a) coefficient was used to calculate the internal consistency of the items in the scales. In terms of the significance of the data obtained from the data groups with each other (p), 0.05 level was taken as the basis.

\section{Results}

Examination of Mathematics Study Strategies of Secondary School Students

The maximum, minimum, arithmetic mean, and standard deviation values obtained for the answers given by students to the scale and sub-dimensions of their study strategies are shown in Table 2.

\section{Table 2}

Examination of the Mathematics Study Strategies of Secondary School Students

\begin{tabular}{lccccc}
\hline Mathematics Study Strategies & $\mathbf{N}$ & Minimum & Maximum & $\bar{X}$ & Sd \\
\hline Time management strategies & 1012 & 1.00 & 5.00 & 3.15 & .917 \\
Executive cognitive strategies & 1012 & 1.00 & 5.00 & 3.40 & .892 \\
Sense-making strategies & 1012 & 1.00 & 5.00 & 3.19 & .829 \\
Organization strategies & 1012 & 1.00 & 5.00 & 3.23 & .905 \\
Repeating strategies & 1012 & 1.00 & 5.00 & 3.03 & .925 \\
Test strategies & 1012 & 1.00 & 5.00 & 3.19 & .889 \\
Total & 1012 & 1.00 & 5.00 & 3.20 & .694 \\
\hline
\end{tabular}

As can be seen in Table 2, when the sub-dimensions of the mathematics study strategies of secondary school students are examined, the students answered "I agree" to executive cognitive strategies ( $\bar{X}=3.40 ; \mathrm{Sd}=.892$ ), which indicates that they are good at these strategies. Secondarv school students answered that they were "indecisive" with regard to time management strategies ( $\bar{X}=3.15$; $\mathrm{Sd}=.917)$, sense-making strategies $(\bar{X}=3.19$; $\mathrm{Sd}=.829)$, ordanization strategies $(\bar{X}=3.23$; $\mathrm{Sd}=.905)$, repeating strategies $(\bar{X}=3.03 ; \mathrm{Sd}=.925)$ and test strategies $(\bar{X}=3.19 ; \mathrm{Sd}=.889)$, which indicated that they were at a medium level with respect to these strategies.

In general, when the mathematics study strategies of secondary school students were examined $(\bar{X}=3.2, \mathrm{Sd}=.694)$, it was seen that the students were at the medium level in mathematics strategies in general as they stated that they were indecisive.

Comparison of mathematics study beliefs of secondary school students according to gender, whether they attended extra-school study centres/preparatory schools, were receiving private tutoring, and grade level variables

The results of the comparison of mathematics study beliefs of secondary school students according to gender, attendance of extra-school study centres/preparatory schools, receiving private tutoring, and grade level variables are examined in Table 3. 
Tezer, M., Gülyaz C. M., \& İlırımlı, A. (2020). Examination of mathematics study strategies of secondary school students from the perspective of multiple variables, International Journal of Cognitive Research in Science, Engineering and Education (IJCRSEE), 8(3), 83-92.

Table 3

Mann-Whitney U-test result with regard to mathematics study strategy beliefs of secondary school students according to gender variable

\begin{tabular}{lcccccc}
\hline Gender & N & Mean rank & $\begin{array}{c}\text { Rank } \\
\text { sum }\end{array}$ & $\mathbf{U}$ & $\mathbf{Z}$ & $\mathbf{P}$ \\
\hline Girls & 480 & 569.04 & 273138.00 & 97662.0 & -6.466 & 0.001 \\
Boys & 532 & 450.08 & 239440.00 & & & \\
\hline
\end{tabular}

When Table 3 is analysed, a significant difference is found between the mathematics study strategies scores of secondary school students by gender [p <0.05] using the Mann-Whitney U-test. As a result of the test, it was determined that the general average score of the female students' mathematics study strategies was higher than that of the male students.

\section{Table 4}

Mann-Whitney U-test result with regard to mathematics study strategy beliefs of secondary school students according to attendance of extra-school study centres/preparatory schools variable

\begin{tabular}{lcccccc}
\hline $\begin{array}{l}\text { Extra-school study } \\
\text { centre/preparatory } \\
\text { school }\end{array}$ & N & $\begin{array}{c}\text { Mean } \\
\text { rank }\end{array}$ & $\begin{array}{c}\text { Rank } \\
\text { sum }\end{array}$ & U & Z & p \\
\hline Yes & 246 & 487.33 & 119882.00 & 89501.0 & -1.183 & 0.237 \\
No & 766 & 512.66 & 392696.00 & & & \\
\hline
\end{tabular}

When Table 4 was analysed, no significant difference was found using the Mann-Whitney U-test between the mathematics study strategies scores of the secondary school students according to whether they attended extra-school study centres or preparatory schools [p>0.05]. In this case, regardless of whether they attended extra-school study centres or preparatory schools or not, the students' mathematics study strategies scores were similar.

\section{Table 5}

Mann-Whitney U-test result with regard to mathematics study strategy beliefs of secondary school students according to private tutoring variable

\begin{tabular}{lcccccc}
\hline \multicolumn{1}{c}{ Private Tutoring } & N & $\begin{array}{c}\text { Mean } \\
\text { rank }\end{array}$ & $\begin{array}{c}\text { Rank } \\
\text { sum }\end{array}$ & U & Z & p \\
\hline Yes & 176 & 498.73 & 87777.00 & 72201.0 & -.388 & 0.698 \\
No & 836 & 508.14 & 424801.00 & & & \\
\hline
\end{tabular}

When Table 5 is examined, it can be seen that there is no significant difference using the MannWhitney U-test between the mathematics study strategies scores of the secondary school students according to whether they were receiving private tutoring [p>0.05]. In this case, regardless of the status of receiving private tutoring, the mathematics study strategies scores of students were similar.

Table 6

Kruskal Wallis-H test result with regard to mathematics study strategy beliefs of secondary school students according to grade variable

\begin{tabular}{llrllll}
\hline & Grade & $\mathrm{N}$ & Mean rank & Sd & $\mathrm{X}^{2}$ & $\mathrm{p}$ \\
\hline Mathematics study & 6. Grade & 197 & 536.82 & & & \\
strategies of students & 7. Grade & 558 & 496.78 & 2 & 2.762 & .253 \\
& 8. Grade & 257 & 504.36 & & & \\
\hline
\end{tabular}

According to the grade variable, no significant difference was found as a result of the Kruskal Wallis-H test in Table 6 when comparing the answers given by secondary school students in terms of their mathematics study strategies according to the grade level ( $p>.05)$. Thus, regardless of the grade levels of 
Tezer, M., Gülyaz C. M., \& Illdırımlı, A. (2020). Examination of mathematics study strategies of secondary school students from the perspective of multiple variables, International Journal of Cognitive Research in Science, Engineering and Education (IJCRSEE), 8(3), 83-92.

the students, it can be said that the answers they provided for their mathematics study strategies beliefs are identical.

The results regarding the comparison of the mathematics study strategies beliefs according to the academic achievement of secondary school students are examined in Table 6. Since the students' academic achievement average is 6.60, students who are lower than this grade are considered to show low academic achievement and students who have a higher score than this grade are considered to show high academic achievement.

Table 7

Mann-Whitney U-test result with regard to mathematics study strategy beliefs of secondary school students according to academic achievement variable

\begin{tabular}{lcccccc}
\hline $\begin{array}{c}\text { Academic } \\
\text { achievement }\end{array}$ & N & Mean rank & $\begin{array}{c}\text { Rank } \\
\text { sum }\end{array}$ & U & Z & p \\
\hline Low & 464 & 444.56 & 206278.00 & 98398.0 & -6.204 & 0.001 \\
High & 548 & 558.94 & 306300.00 & & & \\
\hline
\end{tabular}

According to the findings in Table 7, a significant difference was found using the Mann-Whitney U-test between the mathematics study strategies scores of secondary school students according to academic achievement $[p<0.05]$. As a result of the test, it was determined that students with high academic achievement had higher average scores on mathematics study strategies than those with low academic achievement.

\section{Discussion}

In this study, independent variables including gender, grade level, status of going to extra-school study centres or preparatory schools, status of receiving private tutoring for mathematics, and the previous year's academic achievement in mathematics of students who were enrolled at secondary schools under Ministry of National Education and Culture (MNEC) of Turkish Republic of Northern Cyprus and their mathematics study strategies were examined collectively and evaluations were made.

As a result of the research conducted, considering the mathematics study strategies subdimensions of secondary school students, it has been found that they were at a higher level in terms of student perceptions for executive cognitive strategies, but they indicated a medium level by stating that they were "indecisive" with regard to strategies such as time-management strategies, sense-making strategies, organization strategies, repeating strategies and testing strategies. When the mathematics study strategies of students are examined in general, it is seen that they are also at a medium level. In his thesis study, Aslan (2008) found time management and repeating strategies to be at a medium level, whereas executive cognitive strategies, sense-making strategies, organization strategies and testing strategies were found to be weak. In his thesis study, Karaduman (2019) concluded that the proportional reasoning skills of students were below average.

In this study, by comparing mathematics study strategies in terms of gender, it was revealed that the general average scores of female students' mathematics study strategies were higher than those of male students. Karaduman (2019), on the other hand, showed in his thesis study that when the proportional reasoning skills were analysed according to the gender factor, the scores obtained by female students from the proportional reasoning skills test were statistically significantly higher than male students. Tezer, Onbasi and Falyali (2018) stated that female and male students may have different learning approaches in mathematics.

Another conclusion of this study is that, regardless of whether they attended an extra-school study centre or preparatory school, the mathematics study scores of students were similar. In addition, it was observed that regardless of whether they were receiving private tutoring, the mathematics study scores of students were also similar.

We can claim that, regardless of their grade levels, the mathematics study strategies of secondary school students are at a similar medium level. In addition, this study examined the learning approaches preferred by secondary school students for learning mathematics courses and they were compared according to grade level. When the results obtained from the research are examined, it can be seen that the students' preference for an in-depth and strategic learning approach is considerably above the middle 
level. The authors of the study stated that this phenomenon could be explained by the exam anxiety experienced by students and the difficulty of the mathematics course, which caused them to prefer a strategic learning approach (Jameson and Fusco, 2014).

Meltzer et al. (2001) examined the perceptions of teachers and students in the context of relationships between making effort, strategies, and academic achievement. Successful students stated that they owed their achievement to their efforts; they also stated that they used learning strategies more effectively. Teachers stated in their explanations that successful students are more diligent and use learning strategies effectively, but students who fail do not make enough effort and cannot use strategies adequately. Similarly, in this study, it was observed that secondary school students with low academic achievement used mathematics study strategies less frequently than students with high achievement. On the contrary, in his study on students employing study strategies and their academic achievement, Akkoyunlu (2003) concluded that the difference between the two variables was not significant. Kumar and Sohi (2013) found a high-level, positive correlation between academic achievement and the study habits of $10^{\text {th }}$ grade students.

\section{Conclusion}

As a result of the research conducted, considering the mathematics study strategies subdimensions of secondary school students, it has been seen that they were at a higher level with regard to their perceptions of executive cognitive strategies, but that students indicated a medium level by stating "indecisive" for time-management strategies, sense-making strategies, organization strategies, repeating strategies and testing strategies. When the mathematics study strategies of students are examined general, it is seen that they are also at a medium level.

As a result of the comparison of mathematics study strategy scores in terms of gender, it can be seen that the general mean scores of female students for mathematics study strategies were higher compared to male students. Another finding is that the mathematics study strategy scores of students are similar regardless of whether they attend extra-school study centres or preparatory schools. In addition, it was also seen that grade level and receiving private tutoring did not make much difference in terms of the mathematics study strategy scores of the students. Generally, it has been observed that secondary school students with high academic achievement use their mathematics study skills better than students with low academic achievement.

\section{Recommendations}

- MoNE should organize activities so that students can make better use of mathematics study strategies with the purpose of increasing their academic performance in mathematics classes and teaching them mathematics courses; course curricula can also be prepared accordingly.

- MNEC can organize events such as conferences and seminars to be attended by school administrations and teachers at classroom settings on improving students' mathematics study strategies.

- MNEC should carry out various studies involving school administrations and teachers at classroom settings that will enable male students to use their mathematics study strategies.

- MNEC should organize the textbooks in a way that will improve students' utilisation of mathematics study strategies.

- An examination of mathematics study strategies with different variables not covered in this research may contribute to program development efforts at secondary school level.

\section{Acknowledgments}

The authors would like to thank to Simon Thompson from Near East University for laguage editing and proofreading.

\section{Conflict of interests}

The authors declare no conflict of interest. 
Tezer, M., Gülyaz C. M., \& Illdırımlı, A. (2020). Examination of mathematics study strategies of secondary school students from the perspective of multiple variables, International Journal of Cognitive Research in Science, Engineering and Education (IJCRSEE), 8(3), 83-92.

\section{References}

Açıkgöz, K. Ü. (2003). Etkili öğrenme ve öğretme [Effective learning and teaching] (6 $6^{\text {th }}$ Ed.). İzmir: Eğitim Dünyası Publications.

Akkoyunlu, A. (2003). A research on academic achievement, the attitudes towards mathematics and learning and studying strategies according to the fields that the $10^{\text {th }}$ grade students chose in high school. Unpublished Master's Thesis. Dokuz Eylül University, Educational Science Institute, İmir.

Arries, J. F. (1999). Learning disabilities and foreign languages: A curriculum approach to the design of inclusive courses. The Modern Language Journal, 83(1), 98-110. https://doi.org/10.1111/0026-7902.00008

Aslan S. (2008). İlköğretim İkinci kademe öğrencilerinin matematik dersindeki çalışma yollarını kullanma durumu [The condition of elementary schools' second grade students' usage of studying strategies at mathematic]. Unpublished Master's Thesis, Abant Izzet Baysal University, Social Sciences Institute, Bolu.

Bergey, B. W., Parrila, R. K., Laroche, A., \& Deacon, S. H. (2019). Effects of peer-led training on academic self-efficacy, study strategies, and academic performance for first-year university students with and without reading difficulties. Contemporary Educational Psychology, 56, 25-39. https://doi.org/10.1016/j.cedpsych.2018.11.001

Büyüköztürk, Ş. (2019). Eğitimde bilimsel araştırma yöntemleri [Scientific research methods in education] (29"th Ed.). Ankara: Pegem Akademi.

Coenders, F. \& Verhoef, N. (2019). Lesson Study: professional development (PD) for beginning and experienced teachers. Professional Development in Education 45(2), 217-230, https://doi.org/10.1080/19415257.2018.1430050

Credé, M., \& Kuncel, N. R. (2008). Study habits, skills, and attitudes: The third pillar supporting collegiate academic performance. Perspectives on Psychological Science, 3(6), 425-453, https://doi.org/10.1111\%2Fj.1745-6924.2008.00089.x

Hoover, J. J., \& Patton, J. R. (1995). Teaching students with learning problems to use study skills: A teacher's guide. Pro-Ed.

Holm, A. J., Hausman, H., \& Rhodes, M. G. (2020). Study strategies and "study drugs": investigating the relationship between college students' study behaviors and prescription stimulant misuse. Journal of American college health, 1-10, https:// doi.org/10.1080/07448481.2020.1785472

Jameson, M. M., \& Fusco, B. R. (2014). Math anxiety, math self-concept, and math self-efficacy in adult learners compared to traditional undergraduate students. Adult Education Quarterly, 64(4), 306-322, https://doi. org/10.1177\%2F0741713614541461

Karaduman, B. (2019). Ortaokul 6., 7. ve 8. sınıf öğrencilerinin orantısal akıl yürütme becerilerini ve matematik dersine yönelik tutumlarının bazı değişkenler açısından incelenmesi: cinsiyet ve sınıf düzeyi perspektifi [Investigation of proportional reasoning skills and attitudes towards mathematics lecture of middle school $6^{\text {th }}, 7^{\text {th }}$, and $8^{\text {th }}$ graduate students on some variables: gender and class level perspective]. (Master's thesis, Başkent Üniversitesi Eğitim Bilimleri Enstitüsü).

Karasar, N. (2006). Bilimsel araştırma yöntemi [Scientific research method] (16 ${ }^{\text {th }}$ Ed.). Ankara: Nobel Yayın Dağıtım.

Kartika, A. (2007). Study skills training: Is it an answer to the lack of college students' study skills? The International Journal of Learning, 14(9), 35-43. https://doi.org/10.18848/1447-9494/cgp/v14i09/45480

Kumar, S., \& Sohi, A. (2013). Study habits of tenth grade students in relation to their academic achievements. Indian Journal of Research, 2(12), 58-60, Retrieved from https://www.worldwidejournals.com/paripex/recent_issues_pdf/2013/ December/December_2013_1388040523_75c39_19.pdf

Lewis, C. C., Perry, R. R., \& Hurd, J. (2009). Improving mathematics instruction through lesson study: A theoretical model and North American case. Journal of mathematics teacher education, 12(4), 285-304, https://doi.org/10.1007/s10857-009$9102-7$

Meltzer, L., Katzir-Cohen, T., Miller, L., \& Roditi, B. (2001). The impact of effort and strategy use on academic performance: Student and teacher perceptions. Learning Disability Quarterly, 24(2), 85-98. https://doi.org/10.2307\%2F1511065

Ministry of Education and Culture, (2016). Annual report 2016, Southern Cyprus. Retrieved, June 11, 2020, from http://www. moec.gov.cy/en/annual_reports/annual_report_2016_en.pdf

Murry, J. P. (1990). Better testing for better learning. College Teaching, 38(4), 148-152, https://doi.org/10.1080/87567555.199 0.10532431

Özden, Y. (1999). Öğrenme ve öğretme [Learning and teaching] (3rd Ed.). Ankara: Pegem Yayıncılık.

Qu, Y., Wang, C., \& Zhong, L. (2009, August). The research and discussion of web-based adaptive learning model and strategy. In International Conference on Hybrid Learning and Education (pp. 412-420). Springer, Berlin, Heidelberg. https://doi. org/10.1007/978-3-642-03697-2_38

Pohl, A. J. (2020). Strategies and Interventions for Promoting Cognitive Engagement. In Student Engagement (pp. 253-280). Springer, Cham, https://doi.org/10.1007/978-3-030-37285-9_14

Rohman, S., Hobri, S. \& Sahnawi, S. (2019). An analysis of students' literacy ability mathematics teaching with realistic mathematics education based on lesson study for learning community. In Journal of Physics: Conference Series (Vol. 1265, No. 1, p. 012004). IOP Publishing. https://doi.org/10.1088/1742-6596/1265/1/012004

Schuster, C., Stebner, F., Leutner, D., \& Wirth, J. (2020). Transfer of metacognitive skills in self-regulated learning: an experimental training study. Metacognition and Learning, 1-23. https://doi.org/10.1007/s11409-020-09237-5

Song, X., Ding, N., Jiang, N., Li, H., \& Wen, D. (2020). Time use in out-of-class activities and its association with self-efficacy and perceived stress: data from second-year medical students in China. Medical Education Online, 25(1), 1759868, https://doi.org/10.1080/10872981.2020.1759868

Tezer, M., Onbasi, D., \& Falyali, H. (2018). Examination of the learning strategies used by secondary school students towards a mathematics course in terms of certain variables. IIOAB JOURNAL, 9(3), 144-151. Retrieved from https://www.iioab. org/lIOABJ_9.S3_144-151.pdf

Umay, A. (2003). Mathematical reasoning ability. Hacettepe University Journal of Education, 24, 234-243. Retrieved from http:// www.efdergi.hacettepe.edu.tr/yonetim/icerik/makaleler/898-published.pdf

Weinstein, C. E., Husman, J., \& Dierking, D. R. (2000). Self-regulation interventions with a focus on learning strategies. In Handbook of self-regulation (pp. 727-747). Academic Press. https://doi.org/10.1016/B978-012109890-2/50051-2

Whitworth, J., Herzog, J., \& Scott, D. L. (2012). Problem-based learning strategies for teaching military social work practice behaviors: Review and evaluation. Advances in Social Work - Special Issue: Military Social Work, 13(1), 112-131. 
Tezer, M., Gülyaz C. M., \& İlırımlı, A. (2020). Examination of mathematics study strategies of secondary school students from the perspective of multiple variables, International Journal of Cognitive Research in Science, Engineering and Education (IJCRSEE), 8(3), 83-92.

https://doi.org/10.18060/1876

Willems, I. \& Bossche, P. V. (2019). Lesson study effectiveness for teachers' professional learning: a best evidence synthesis. International Journal for Lesson and Learning Studies 8(4), 257 271, https://doi.org/10.1108/IJLLS-04-2019-0031

Woolfolk, A. E (1993). Educational Psychology. Boston: Allyn and Bacon.

Yaman, H., Toluk, Z., \& Olkun, S. (2003). How the elementary school students would perceive equal sign. Hacettepe Universitesi Egitim Fakultesi Dergisi, 24, 142-151, Retrieved from http://www.efdergi.hacettepe.edu.tr/shw_artcl-878.html 